\title{
National Library Week celebrates connections
}

\author{
By Linda Wallace
}

Celebrate National Library Week, April 13-19, 1997

$\mathbf{N}$ ational Library Week, April 13-19, will celebrate the ways libraries connect children with fun and learning. The theme is "Kids Connect @ the Library." If you think the theme doesn't connect with your college or university library, think again. Some suggestions:

- Join in giving tours of the information superhighway on Wednesday, April 16, as part of the second Log-on (a) the Library Day. An estimated thousand libraries participated in the first event held in 1996, including Northeastern State University in Tahlequah, Oklahoma, population 10,500, which conclucted Internet demonstrations for local high school students and the public. Have staff wear "Cybrarian" sports hats and t-shirts available from the ALA Graphics catalog.

- Encourage faculty and students to enter the Kids Connect @ 9 the Library Contest. A $\$ 20,000$ grand prize will be awarded for the best 150 words from a parent about how the library helps his or her family connect to books, computers, better grades, free fun, and more. Contact the ALA Public Information Office for a free poster/tip sheet.

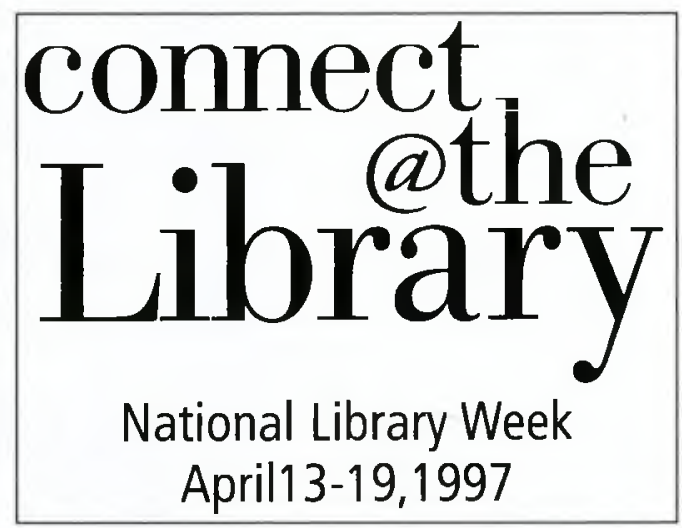

- Display the handsome National Library Week materials available from ALA Graphicsnot in the library but in campus day care centers and School of Education facilities. The Bank Street College of Education in New York will sponsor a folklore festival with children and adults telling folk tales to one another.

- Get rid of the "kid." Make your own posters and banners with a shortened version of the theme "Connect @ the Library." Publish a David Letterman style list of 10 ways you can connect at the campus library. Number 10: Where else can you hunker down for days on end skipping classes and have everyone think you're a model student? Number 1: Where else can you find...? (fill in the blank).

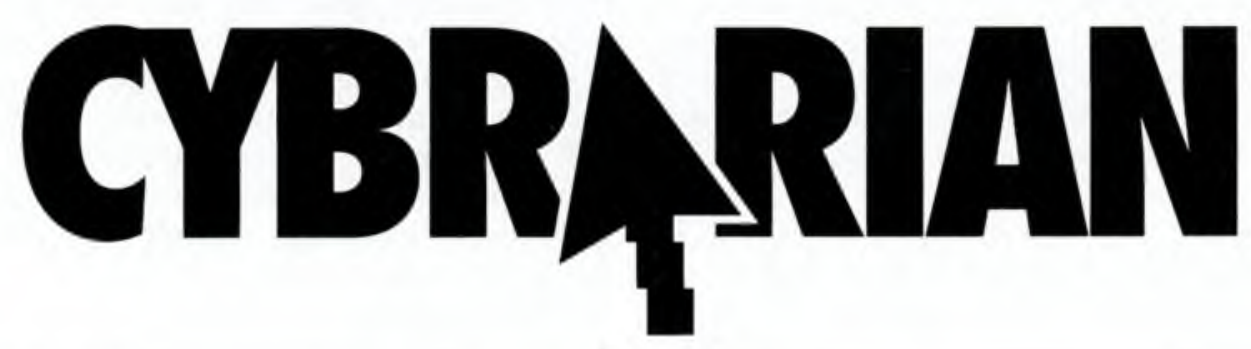

Linda Wallace is director of the ALA Public Information Office, e-mail: hwallace@ala.org; Mary Somerville is director of the Miami-Dade Public Library System and president of ALA; mpres@dcfreenet.seflin.lib.fl.us 


\section{Kids can'\$ wait . . . Library Advocacy Now!}

\section{By Mary Somerville}

ALA Goal 2000 calls for the American Library Association to play a leadership role in advocating the public's right to a free and open information society, one in which all people can fully participate. I am focusing my year as ALA president on raising public awareness and support for library services to youth. Why? Because kids who aren't logged on and literate will be lost in the 21st century. And they will not be able to participate fully in our democracy.

School and public libraries have a critical role to play in turning kids into readers and teaching them the computer skills they will need to succeed later in college and throughout life. No one understands this better than you who work in higher education. In fact, many college and university libraries are actively reaching out to youth in their communities.

These activities take many forms. At some schools, such as York College of Pennsylvania, Western Kentucky University, and Utah State University, staff speak regularly with $4-\mathrm{H}$, scouts, and other youth groups about career opportunities. A growing

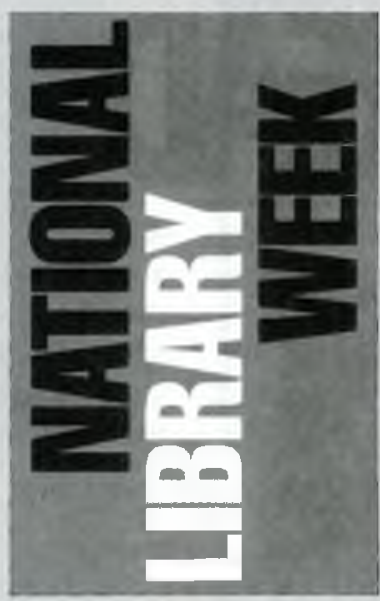
children will learn at an early age the benefits of using and supporting libraries.

Together we must persuacle community leaders and state and national legislators that an investment in libraries is an investment in the future of our youth and this country. As a representative of higher education, you are in a position to speak with authority about the importance of preparing children to be information literate. If each of us cloes only three things this year, collectively we can make a dramatic difference. I urge you to:

1) Reach out to school and public libraries in your area. Find out how and what you can do to support their efforts. In South Bend, Indiana, elementary students who previously received failing grades now earn A's, thanks to students from Holly Cross College who conduct volunteer tutoring sessions at the public library.

2) As a public advocate, speak out before community groups, the League of Women Voters, and church and temple groups about the importance of library services to children. Show the free vicleo "Kids can't wait" (see Resources on next number, such as the University of New Orleans Earl K. Long Library, the University of Illinois at Chicago, and the University of California, Riverside, Library are providing technical assistance and instruction to help get local schools connected to the Internet. Many, especially those in low income and rural areas, regularly open their doors to elementary and high school students for library instruction and research. The University of Tennessee's Scholars in Schools program places three faculty members, including one from the library, in local schools to work on programs tied to their expertise during the school year.

Needless to say, it is in our own professional self-interest to advocate libraries that are wired, well stocked, and staffed so that page). Encourage members of the public to express their support for libraries to public officials.

3) Support ALA's national campaigns. Celebrate National Library Week. Become a member of the Library Advocacy Now! Network. Attend a library advocacy training session at an ALA conference or organize a workshop for libraries in your comnunity or state. Call, write, or visit your community leaders, state legislators, and members of Congress to discuss issues of concern to libraries (see Resources on next page).

Library advocacy is critical to the future of our children but it's not kid stuff, and it requires the commitment of all of us. Kids can't wait. 
- Take the America Reads Challenge. President Clinton has set a goal of having all children reading indepenctently by third grade. His challenge provides a timely opportunity for librarians to take a leadership role. Start or join a coalition of libraries and community agencies concerned with youth. Mobilize your students as volunteer tutors to help children improve their reading skills.

- Write and place a story in the local newspaper about how technology is revolutionizing libraries as did Marcia IDworak, director of the Thorndike Library at the College of the Atlantic, with help from the college's public affairs clirector during National Library Week 1996 . Write a letter to the editor or an editorial column for the local newspaper. See ALA's "Kids can't wait" National Library Week tip sheet for examples (available on the ALA Web page or from the Public Information Office).

- Post a National Library Week message on your Internet homepage. Send e-mail messages inviting administrators, faculty, and others to the library for coffee, door prizes, and other festivities.

- Get students involved as library advocates. Recruit campus sports stars to visit schools and public libraries in the community and talk about the importance of reading and using the library.

\section{Resources}

- Colorful posters, t-shirts, and other library promotional items with the "Kids Connect @ the Library" theme (and without) can be ordered from the fall ALA Graphics catalog. To receive a free catalog, call (800) 545-2433, ext. 5046. To place an order, call (800) 545-2433, press 7 . For bulk or institutional sales use ext. 3252.

- Kids can't wait . . Kids Need Libraries, a handsome, photo-filled brochure directed at community leaders and policymakers is available from the ALA Public Information Office; phone: (800) 545-2433, ext. 5044/41; fax: (312) 9448520; e-mail: pio@ala.org.

- Kids can't wait ... Library Advocacy Now, President's Paperby Virginia Mathews. Single copy, free. $\$ 25 / 25$ copies. Contact the ALA Public Information Office (see above).

- Kids can't wait .. . , a free videotape with ALA President Mary Somerville discussing why "kids can't wati" and how the public can support libraries. Designed for showing to the public. Contact the ALA Public Information Office (see above).

- The Library Advocacy Now! Network provides training and support materials and alerts on key national legislative issues. Free. Contact the ALA Public Information Office (see above). To sign on to the ALA Library Advocacy Now! listserv, send a message to listproc@ala.org. Leave the subject blank. In the body type: "subscribe aladnow" followed by your first and last name.

- Subscribe to the ALA Wasbington Office Newsline, an online newsletter offering timely updates on federal legislation and policies. Send the e-mail message described above. The list name is ala-wo.

For more information about National Library Week and ALA's advocacy efforts, see the ALA Web page at http://www.ala.org. Or contact the ALA Public Information Office, $50 \mathrm{E}$. Huron St., Chicago, IL 60611; (800) 545-2433, ext. 5044/41; fax: (312) 944-8520; e-mail: pio@ ala.org. 


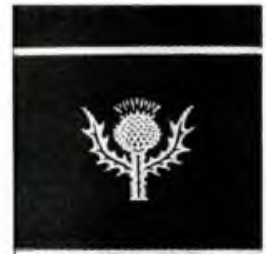

\section{The evolution of} a classic.
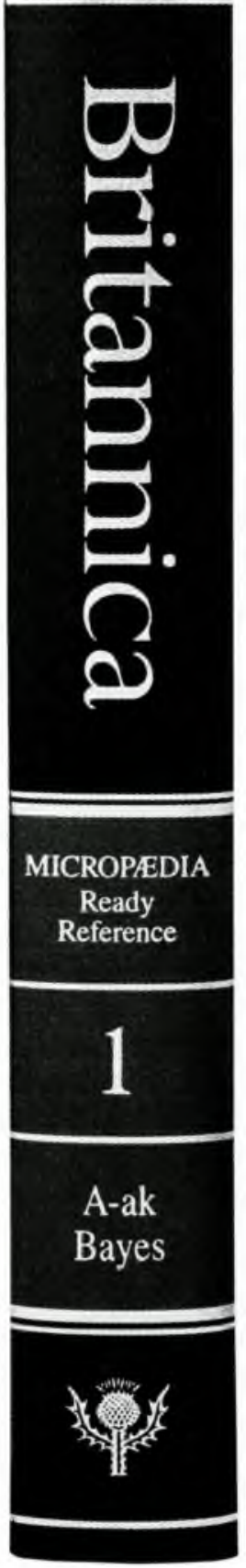

You've trusted Britannica for years, and as the information needs of schools and libraries have changed, so have we. Britannica Online the first encyclopedia on the Internet - is already used by more than three million students at hundreds of the most prestigious universities in the world. And now it's available to answer your questions in your library, anytime. It's fast, it's convenient, and because it's Britannica, it's the right answer!

For a free two-week preview of Britannica Online 97, call 1-800-621-3900 or visit http://www.eb.com today.

The 1997 version features: - Almost 1000 new graphics - Over 5000 related Internet links. Thumbnails of images in the text - Updated content $\cdot$ and more!

\section{Britannica}

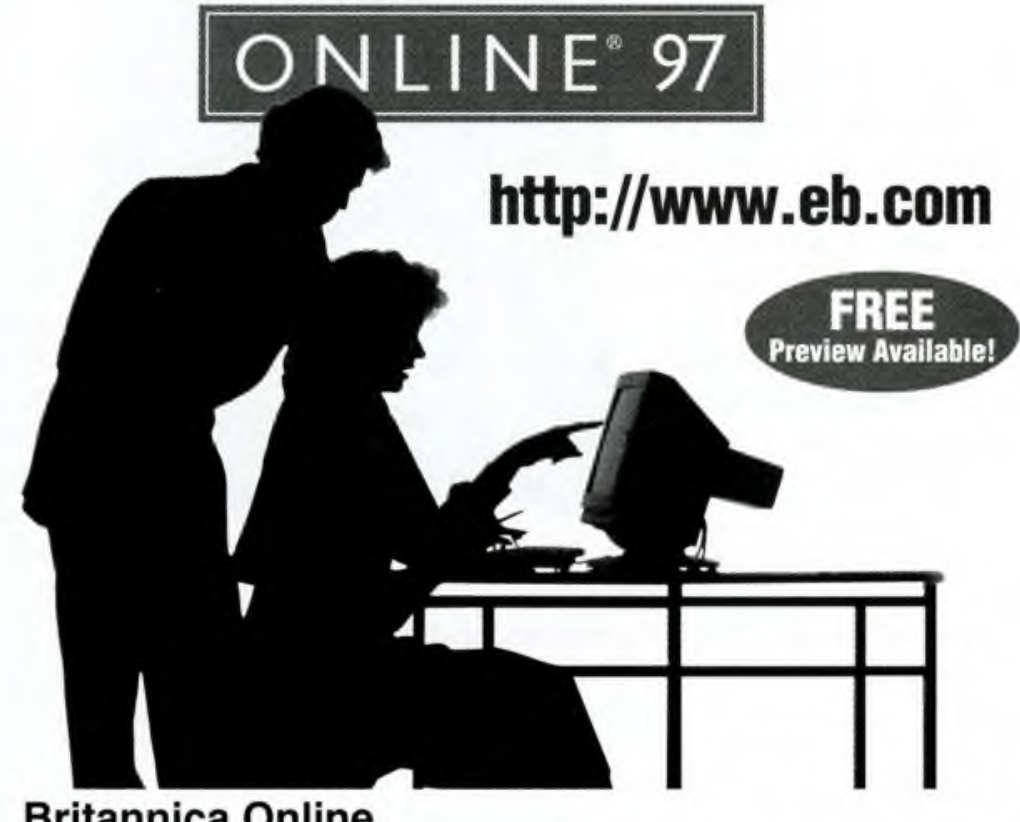

Britannica Online

From the editors of ENCYCLOPÆDIA BRITANNICA: 